\title{
Evidence for a correlation between total lead concentrations in soils and the presence of geological faults
}

\author{
Marcos R. Moreira-Silva ${ }^{1}$ - Carlos A. Tello Sáenz ${ }^{2}$ João O. Rodrigues Nunes ${ }^{3}$. \\ Manoel Godoy ${ }^{3} \cdot$ Marcos F. S. Teixeira $^{1}$ (D)
}

Received: 1 February 2017 / Accepted: 23 February 2017/Published online: 3 March 2017

(C) Springer International Publishing Switzerland 2017

\begin{abstract}
The emission of radon gas in regions of geological faults, during the radioactive decay of uranium and thorium, results in the formation of lead isotopes ${ }^{210} \mathrm{~Pb}$, ${ }^{208} \mathrm{~Pb},{ }^{207} \mathrm{~Pb}$ and ${ }^{206} \mathrm{~Pb}$. As a consequence, the lead contamination in the soil poses a hazard to humans through ingestion of food, contaminated water, and even by direct contact with the soil contaminant. So far the relationship between the occurrence of geological faults and soil $\mathrm{Pb}$ contamination has not been established. Here, we studied lead in soils of regions with geological faults and their possible relationship with radon emissions. Soils were sampled from Presidente Prudente located in the far west of São Paulo State, Brazil. The region has strong evidence of the existence and direction of geological faults at depths of approximately $200 \mathrm{~m}$. Soil sampling was done according to the USEPA 3050 method. Total lead was quantified by anodic stripping voltammetry. Results show that the total $\mathrm{Pb}$ concentration increases systematically with soil depth. This finding is explained by the fact that the lead originates from radon emissions. Pearson correlation analysis further proves a relationship of the nuclear track density obtained with CR-39 detectors, and mean $\mathrm{Pb}$ levels within each soil profile. Overall, our findings should improve risk
\end{abstract}

Marcos F. S. Teixeira

funcao@fct.unesp.br

1 Department of Chemistry and Biochemistry, Faculty of Science and Technology, São Paulo State University (UNESP), Presidente Prudente, SP, Brazil

2 Department of Physics, Faculty of Science and Technology, São Paulo State University (UNESP), Presidente Prudente, SP, Brazil

3 Department of Geography, Faculty of Science and Technology, São Paulo State University (UNESP), Presidente Prudente, SP, Brazil evaluation of $\mathrm{Pb}$ contamination derived from radon emission and geological faults.

Keywords Geological fault · Soil lead availability · Geochemical contamination $\cdot \mathrm{Pb}$

\section{Introduction}

Metals normally occur naturally in the soil at low concentrations, due to weathering and pedogenic processes that act on the rock. Changes in metal concentrations can occur over time, influenced by biochemical processes as well as anthropogenic action. Among the metals, lead has a longer residence time in the soil, compared to many other environmental pollutants (Alloway et al. 1990). Anthropogenic activities can result in higher concentrations of this metal in soils, mainly due the use in automotive fuel additives, industrial activities, fertilizers, and the widespread use of insecticides (Lagerwer and Specht 1970). The duration of $\mathrm{Pb}$ contamination in soils depends on factors such as local climate, hydrology, and the soil composition (Bielicki and Tischendorf 1991; Ming et al. 2012; Turpeinen et al. 2000; Yang and Appleby 2016). Usually, the lead in soil occurs at concentrations that range from 10 to $50 \mathrm{mg} / \mathrm{kg}$ (Hettiarachchi and Pierzynski 2004). The lead contamination of the soil can pose a hazard to humans through ingestion of food, contaminated water, and even in direct contact of the contaminant (Elom et al. 2014; Miretzky et al. 2007; Zia et al. 2011).

The emission of radon gas in regions of geological faults, during the radioactive decay of uranium and thorium, also results in the formation of lead as the most stable element (Amaral et al. 2012). Regions with high levels of radon emissions may be affected by neotectonic 
processes such as volcanism, hydrothermal activity, differences between the temperatures of the internal and external environments, humidity, karstic geomorphology, porosity of rocks, and earthquakes (Batiot-Guilhe et al. 2007; Chyi et al. 2005; Espinosa et al. 2008a, b; Kharatian et al. 2002; Kuptsov 1990; Yang et al. 2005). In Brazil, the west of São Paulo State, including the municipality of Presidente Prudente, is of interest for neotectonic studies, due to characteristics including gentle relief, intense chemical weathering, evidence of seismicity, and presence of hydrothermal areas (Assumpcao et al. 2002; Godoy 2006).

The present study investigates the relation between total lead concentrations $\left({ }^{210} \mathrm{~Pb},{ }^{208} \mathrm{~Pb},{ }^{207} \mathrm{~Pb}\right.$, and $\left.{ }^{206} \mathrm{~Pb}\right)$ in soils of regions with geological faults and their correlation with possible radon emissions. The findings are compared with results for areas free from geological faults. Evaluation was made of the influence of soil depth and particle size on total lead concentrations. The findings of the work are relevant for the evaluation of risks to public health due to contamination with bioavailable lead derived from radon emissions (Bochicchio et al. 1998; Poortinga et al. 2011). Recently, we explored the assessment of atmospheric deposition in Presidente Prudente (Proença et al. 2016). In the study, a high concentration of lead was observed in atmospheric particulate due to the proximity of geological faults. This fact motivated us to conduct this study.

\section{Experimental}

\section{Collection site}

The study region was in the municipality of Presidente Prudente $\left(22.12^{\circ} \mathrm{S}, 51.40^{\circ} \mathrm{W}\right)$, located in the far west of São Paulo State, Brazil. According to the Brazilian Institute of Geography and Statistics (IBGE), the municipality has a population of about 207,625 inhabitants, with 4255 in rural areas and 203,370 in urban areas. In this region, there is strong evidence of the existence and direction of geological faults at depths of approximately $200 \mathrm{~m}$ that are characteristic of regions with geothermal activity.

The areas chosen for the collection of soil samples were based on previous studies of radon emissions using a CR39 solid state nuclear track detector (SSNTD) (Matiullah et al. 1990; Pereira et al. 2013). Use was also made of fluvio-morphometric parameters and paleoseismological data to obtain a representative mapping of the likely neotectonic alignments in the region (Fig. 1a). As a result, six sampling points were identified within the main study area (Fig. 1b), together with two sampling points outside the geological fault zone, in the District of Montalvão (distance of $15 \mathrm{~km}$ from the sampling point).

\section{Collection of discrete samples in the fault region}

Sample collection in the region identified with geological faults (P1-P6 points-Fig. 1a) was based on procedures described in the literature (Carter and Gregorich 2008; Tack and Verloo 1995). Samples were manually obtained at three different depths $(15,30$, and $60 \mathrm{~cm})$, using a cuptype auger.

\section{Collection of soil cores at background sites}

The core sampling method was used for the collections at P7 and P8 points in a region distant from the area with supposed faults. This technique was adopted because it maintained the original profile of the soil structure, so that the cores could be subsequently relocated in vertical bores dug in the fault area. The soil cores were extracted using 60-cm polyvinyl chloride tubes. Samples were then removed at depths of 15,30 , and $60 \mathrm{~cm}$ in the cores.

\section{Installation of bores}

In this phase of the work, the cores removed at P7 and P8 points were installed in the fault region in order to measure the effects of high levels of radon emissions on the lead concentrations. Bores were dug using an excavator with diameter and length close to that of the PVC tubes, in order to ensure a good fit of the soil cores. The tubes containing the cores from $\mathrm{P} 7$ and $\mathrm{P} 8$ points were placed in the bores and incubated for 95 days. Soil samples were then collected at the three different depths using a cup-type auger.

\section{Pretreatment of the soil samples}

The soil samples were dried in an oven for $24 \mathrm{~h}$ at a temperature of around $100{ }^{\circ} \mathrm{C}$, then macerated in a porcelain crucible and divided into three representative portions. Acid digestion was performed according to USEPA Method 3050 (Chen and Ma 1998).

\section{Analysis of total lead by voltammetry}

The analysis of all lead isotopes (total lead concentrations) in soil was realized by anodic stripping voltammetry (Model 797 VA, Metrohm). This method is a good method of analysis for a mixture of radioactive isotopes because it does not require the forehand knowledge to add an inactive carrier to the unknown solution as it does in most other radiochemical procedures (Katsanos et al. 1966; Raaen 1974).

The electrochemical cell consisted of a hanging mercury drop working electrode, an $\mathrm{Ag} / \mathrm{AgCl} / \mathrm{KCl}(3 \mathrm{M})$ reference electrode, and a platinum (Pt) auxiliary electrode. Firstly, $20 \mathrm{~mL}$ of $\mathrm{NaNO}_{3}$ solution was added to the 
(a)

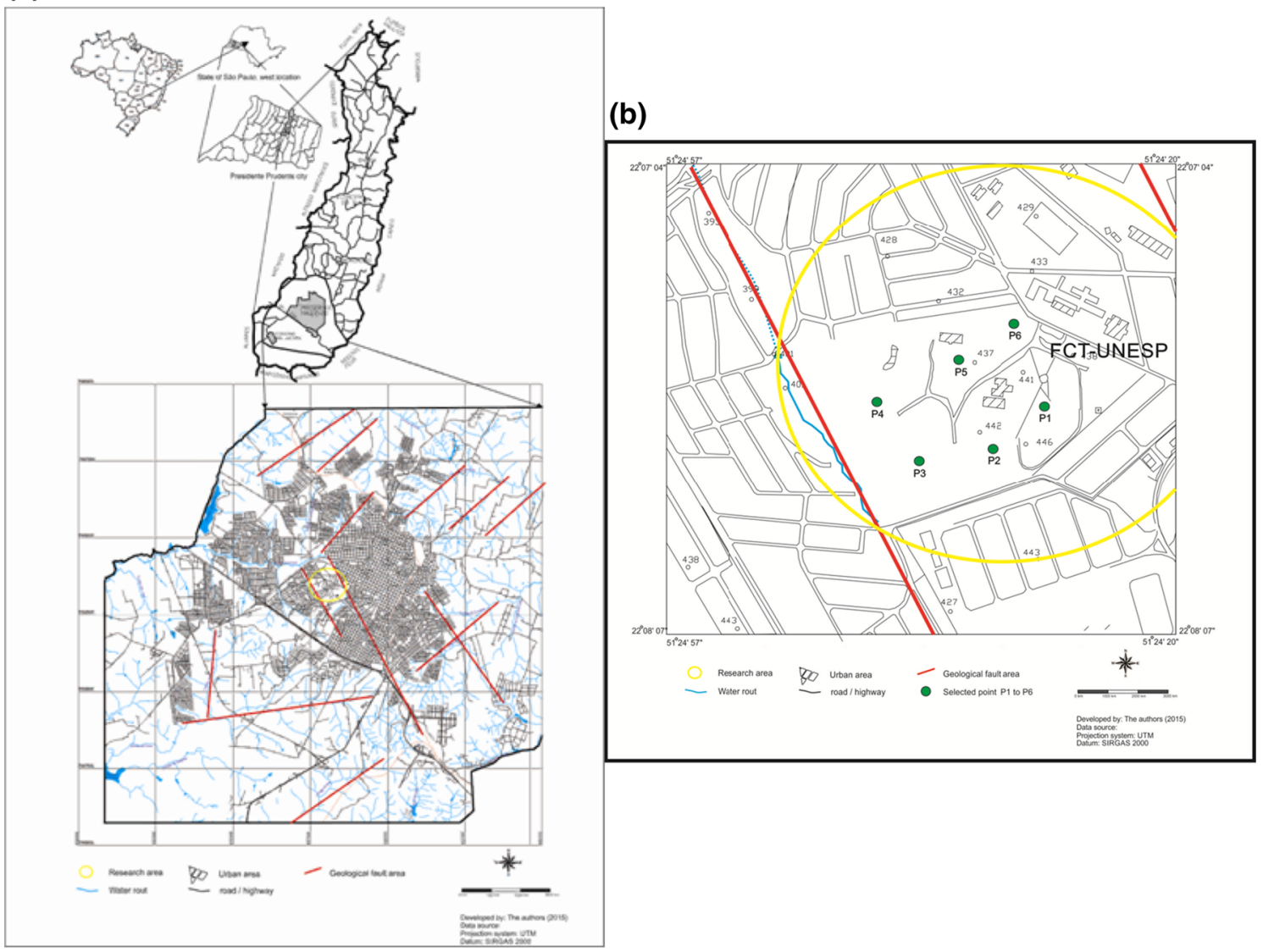

Fig. 1 Maps of the research region. a Presidente Prudente region with the occurrence of zones with geological fault (red lines). b Collection sites near of the lines designate geological faults

electrochemical cell as the support electrolyte for the $\mathrm{Pb}$ determinations, followed by degassing with nitrogen for $5 \mathrm{~min}$. With the electrode potential set to a sufficiently negative value to reduce the ions to their metallic form, the pre-concentration step was performed for $30 \mathrm{~s}$ at $-1.2 \mathrm{~V}$ (vs. $\mathrm{Ag} / \mathrm{AgCl}$ ), under constant agitation, in order to concentrate the metals onto the electrode surface from a $2 \mathrm{~mL}$ volume of sample. The solution was allowed to stand for a few seconds for the system to reach equilibrium. After the pre-concentration step, the potential was scanned from -0.6 to $-0.2 \mathrm{~V}$, at $5 \mathrm{mV} \mathrm{s}^{-1}$, in order to re-oxidize and redissolve the analyte $(\mathrm{Pb})$. Hence, it was possible to obtain the peak current value corresponding to $\mathrm{Pb}$. The total lead contents in the samples were obtained individually using the multiple standard additions method (in quintuplicate). All trends are statistically significant at the $95 \%$ level using a Student's $t$ test.

\section{Granulometric analysis}

Determination of the particle size distribution of soils that contain particles in both the coarse fraction (sand and gravel) and the fine fraction (silt and clay) employs a sieving procedure based on Stokes Law, using the terminal sedimentation velocity of particles in an aqueous medium. The textural analysis followed the norms of the Manual of Methods of Soil Analysis, using the pipette method (Lerman et al. 1974).

\section{CR-39 detectors}

The study of the emanation radon from soils was made almost in parallel with its relation with chemical analysis. Among the various solid state nuclear track detectors, the organic polycarbonate-based CR-39 device (allyl diglycolcarbonate, $\mathrm{C}_{12} \mathrm{H}_{18} \mathrm{O}_{7}$ ) is one of the most effective commercially available options. It is totally amorphous and enables the recording of tracks resulting from certain types of radiation that cause permanent damage to its structure (Knizhnik et al. 1994). The CR-39 detectors were exposed near P7 and P8 points (outside the geological fault zone), and in the region of the geological faults where the bores were installed. The detectors were centrally attached with adhesive tape to the interior of the base of labeled plastic 
flasks. The CR-39 detectors were inside of buckets with approximately $40 \mathrm{~cm}$ of diameter and $50 \mathrm{~cm}$ of length (located about $30 \mathrm{~cm}$ deep and protected with wooden to avoid any external influence as some undesirable human movement or some environmental conditions. The exposure sites were duly signposted, and the exposure was performed for 95 days. After exposure, the CR-39 substrates were treated using concentrated $\mathrm{NaOH}$ solution (6.25 mol/L), with heating in an ultrathermal bath at $70{ }^{\circ} \mathrm{C}$ for $400 \mathrm{~min}$. Subsequently, the CR-39 substrates were neutralized with saturated $\mathrm{NaHCO}_{3}$ solution and washed abundantly with water. Observation and counting of the tracks, using microscopy, was performed perpendicular to the detector surface, with the tracks appearing as ellipses, circles, or elongated structures, depending on the angle of incidence and the energy of the alpha particle. A Carl Zeiss optical microscope was used, with a $40 \times$ objective lens and a 10x eyepiece, coupled to an Axio Cam MRC5 digital camera and a computer running Axio Vision software. The standard deviation average was calculated considering Poisson Distributions of the tracks.

\section{Statistical analysis}

Relationships between nuclear tracks density and total $\mathrm{Pb}$ concentration were assessed by use of the IBM SPSS Statistic 23 program (IBM Corp., New York) to arrive at Pearson correlation coefficients.

\section{Results and discussion}

\section{Concentrations of total lead in the soil samples}

Table 1 shows the results of the quantitative analysis of $\mathrm{Pb}$ in the soil samples obtained at different depths at the various sampling points. In this type of analysis, it is probable that the highest amount of lead determined is ${ }^{210} \mathrm{~Pb}$ (halflife $=22.3$ years) and ${ }^{206} \mathrm{~Pb}$. However, we have to consider the contribution of ${ }^{208} \mathrm{~Pb}$ coming of the ${ }^{232} \mathrm{Th}$ and with less quantity the ${ }^{207} \mathrm{~Pb}$ by U-235 decay chains.

The soil samples from the area of fault lines (P1 to P6 points) showed $\mathrm{Pb}$ concentrations in the range from 271.22 to $843.30 \mathrm{mg} \mathrm{kg}^{-1}$, which exceeded both the reference and prevention values, and were above the level at which intervention is required (for residential areas, the limit is $240 \mathrm{mg} \mathrm{kg}^{-1}$ ). The results indicated lead concentration exceedances ranging from 113 to $351 \%$ in soil samples collected in the geological fault areas.

The $\mathrm{Pb}$ concentrations at $\mathrm{P} 7$ and $\mathrm{P} 8$ points (outside the area of faults) varied from 6.83 to $15.9 \mathrm{mg} \mathrm{kg}^{-1}$ and were therefore far lower than in the fault areas. These concentrations were similar to total lead concentrations observed
Table 1 Concentration level of total lead in different depths for the soil samples $(n=5)$ with respective concentrations of clay

\begin{tabular}{|c|c|c|c|}
\hline Collection point & Depth $(\mathrm{cm})$ & {$[\mathrm{Pb}]\left(\mathrm{mg} \mathrm{kg}^{-1}\right)$} & Clay $\left(\mathrm{g} \mathrm{kg}^{-1}\right)$ \\
\hline \multirow[t]{3}{*}{ P1 } & 15 & $338.00 \pm 0.48$ & 17.00 \\
\hline & 30 & $556.12 \pm 1.41$ & 82.89 \\
\hline & 60 & $683.76 \pm 1.87$ & 193.34 \\
\hline \multirow[t]{3}{*}{$\mathrm{P} 2$} & 15 & $369.23 \pm 0.45$ & 77.00 \\
\hline & 30 & $610.82 \pm 0.55$ & 84.01 \\
\hline & 60 & $843.30 \pm 0.27$ & 103.45 \\
\hline \multirow[t]{3}{*}{ P3 } & 15 & $355.50 \pm 0.87$ & 93.33 \\
\hline & 30 & $508.26 \pm 1.96$ & 102.62 \\
\hline & 60 & $790.88 \pm 0.62$ & 125.00 \\
\hline \multirow[t]{3}{*}{$\mathrm{P} 4$} & 15 & $271.22 \pm 0.43$ & 126.40 \\
\hline & 30 & $300.85 \pm 0.77$ & 137.00 \\
\hline & 60 & $453.56 \pm 0.29$ & 146.00 \\
\hline \multirow[t]{3}{*}{ P5 } & 15 & $373.78 \pm 0.18$ & 64.00 \\
\hline & 30 & $407.97 \pm 0.37$ & 66.00 \\
\hline & 60 & $449.00 \pm 0.46$ & 102.28 \\
\hline \multirow[t]{3}{*}{ P6 } & 15 & $647.29 \pm 0.99$ & 93.58 \\
\hline & 30 & $613.10 \pm 2.04$ & 82.00 \\
\hline & 60 & $727.06 \pm 1.28$ & 142.00 \\
\hline \multirow[t]{3}{*}{$\mathrm{P}^{\mathrm{a}}$} & 15 & $6.83 \pm 2.58$ & 141.00 \\
\hline & 30 & $9.11 \pm 0.56$ & 168.00 \\
\hline & 60 & $13.67 \pm 1.77$ & 188.66 \\
\hline \multirow[t]{3}{*}{$P 8^{\mathrm{a}}$} & 15 & $11.39 \pm 2.15$ & 120.01 \\
\hline & 30 & $13.67 \pm 2.54$ & 244.00 \\
\hline & 60 & $15.95 \pm 2.29$ & 386.00 \\
\hline
\end{tabular}

The concentrations of lead were higher in the horizons with greater percentages of clay

a Sites outside the area geological fault

in rural regions of Australia, where levels of up to $14 \mathrm{mg} \mathrm{kg}^{-1} \mathrm{~Pb}$ were measured (Olszowy et al. 1995), and could therefore be classified as normal. Hence, these soil profiles were used for comparison with the soils analyzed in the fault areas. According to the data shown in Table 1, the $\mathrm{Pb}$ concentration increased with soil depth, with lower lead concentrations in the shallowest horizons $(15 \mathrm{~cm})$, compared to the deepest horizons $(60 \mathrm{~cm})$. This behavior can be explained by the fact that the source of the lead was radon emissions, with $\mathrm{Pb}$ being the most stable element in the decay series, which in turn also suggests the existence of a geological fault (Inan et al. 2012; Nevinsky et al. 2012; Yang et al. 2005). It is possible that soil leaching could transfer the metal to deeper horizons. However, at the collection sites there were no substantial external anthropogenic sources of lead that could explain the measured concentrations, further supporting the hypothesis that the metal originated from $\mathrm{Rn}$ emissions. The difference in concentration toward the surface may be related to the diffusion of radon that ever smaller in this direction. 


\section{Concentrations of $\mathrm{Pb}$ in soil samples incubated in bores in the geological fault region}

Figure $2 \mathrm{a}, \mathrm{b}$ illustrates the increases in the $\mathrm{Pb}$ concentrations in the soil cores retrieved from outside the geological fault zone, at time $=0$ and after incubation in the bore (time $=95$ days). There were substantial increases in the lead concentrations after the incubation period, which exceeded 4150, 2376, and $200 \%$ in the 60, 30, and 15 horizons of the P7 core, respectively. In the case of the P8 core, the deepest horizon $(60 \mathrm{~cm})$ showed an increase in the $\mathrm{Pb}$ concentration exceeding $3740 \%$, while an increase of $180 \%$ was observed for the $15 \mathrm{~cm}$ horizon. The large

(a)

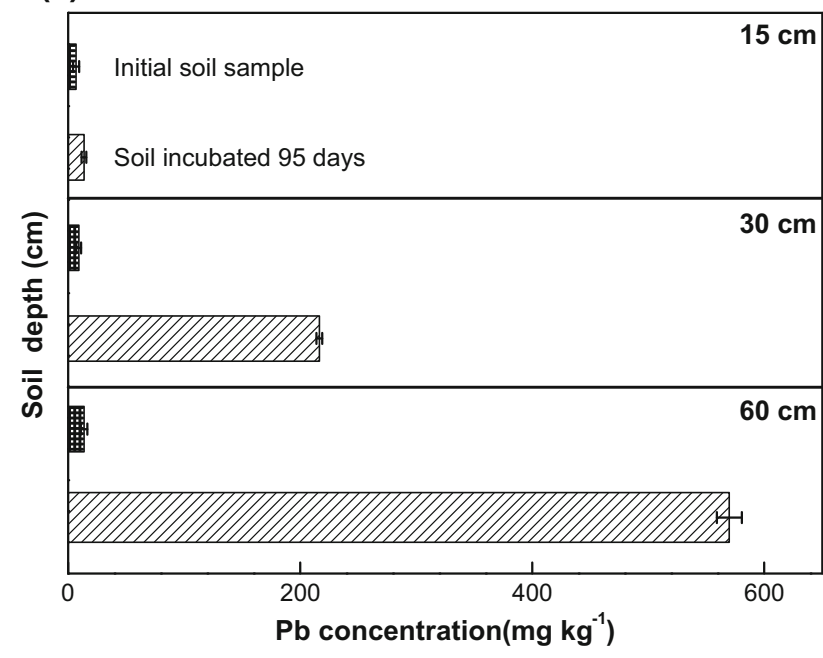

(b)

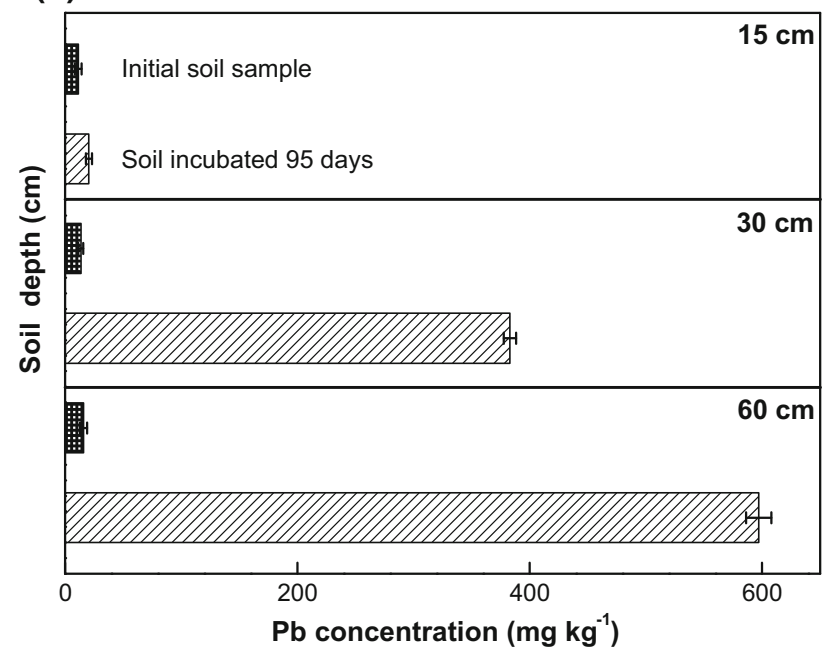

Fig. 2 Changes in total $\mathrm{Pb}$ concentrations $(n=3)$ in different depths of the soil core collected at point P7 (a) and point P8 (b) after incubation in the bore for 95 days in area with geological fault. The error bars represent the $95 \%$ confidence interval. The large increases in $\mathrm{Pb}$ concentrations revealed the influence of the geological fault on soil $\mathrm{Pb}$ levels increases in $\mathrm{Pb}$ concentrations revealed the influence of the geological fault on soil $\mathrm{Pb}$ levels. The greatest increases were observed for the $60 \mathrm{~cm}$ horizons, indicating the direct influence of radon emissions, which originated below the bases of the soil cores, in the anomalies of the underlying rock layers (which were assumed to be due to geological faults).

Another possible (albeit less likely) reason for the increased $\mathrm{Pb}$ concentrations is related to the meteorology; under the influence of precipitation, $\mathrm{Pb}$ might be leached to deeper soil horizons. However, it is unlikely that lead would be liable to any substantial transport according to this mechanism. Due to a relatively long half-life time ${ }^{210} \mathrm{~Pb}$ is the sole natural radioactive lead isotope, the presence of which in the environment is directly related to the presence of the parent isotope in which the state of secular radioactive equilibrium relatively quickly.

Due to a relatively long half-life time of the $\mathrm{Pb}$, the total lead concentration is directly related to the presence of the parent isotope where the state of secular radioactive equilibrium relatively quickly (Chmielewska et al. 2014). Its concentration can vary depending geophysical factors such as hydrothermalism and earthquakes that can facilitate the emanation of radon.

\section{Granulometric evaluation}

The results of the textural analysis showed that most of the soil samples contained high percentages of the sandy fraction and could be classified as light sandy and sandy, with the exception of P8 point, where higher clay contents resulted in classification as light sandy loam and sandy loam. The clay fraction percentages at the collection points varied from 1.8 to $38.6 \%$. It is known that the concentration of lead in soil is influenced by the amounts of humus, organic matter, and clay, with the amount of clay being most important in the case of tropical soils (Kabata-Pendias and Mukherjee 2007). It has been reported that more than $43 \%$ of the lead present in soil is found in the organic soil fraction, with the remainder bound to other components of the soil system, such as oxides and hydroxides of iron and aluminum, as well as carbonates and phosphates (Shaheen et al. 2013; Xian 1989). An excess of negative charges on the surfaces of the soil particles results in the attraction of cations from the soil liquid phase and other particles (Kurczewska et al. 2015). This adsorption process, involving weak and reversible ionic bonding, is known as the cation exchange capacity (CEC). Particles with high specific surface area have higher CEC, notably in the case of particles in the clay fraction, where silicon $\left(\mathrm{Si}^{4+}\right)$ and aluminum $\left(\mathrm{Al}^{2+}\right)$ ions can be substituted by $\mathrm{Pb}^{4+}$ and $\mathrm{Pb}^{2+}$, respectively (Alleoni et al. 2009). 
The concentrations of lead were higher in the horizons with greater percentages of clay (Table 1), in agreement with the cation exchange capacity of this soil fraction. The concentrations of clay in the samples collected from the P7 and P8 points were higher than found for the other locations, and increased with depth of the soil profile. However, the lead concentrations were lower, compared to P1-P6 points, indicating that in this region the availability of the metal was low, independent of the origin (natural or anthropogenic). This was further supported by the fact that after incubation in the bores, the P7 and P8 soil cores showed increases in lead concentrations that were influenced by the availability of clay, with the deepest horizons $(60 \mathrm{~cm})$ with highest clay contents presenting the highest metal concentrations.

\section{Evaluation using CR-39}

The CR-39 was used only as a comparative analysis between the studied areas. The detectors exposed at P7 and P8 points showed similar density values of $4.77 \times 10^{4}$ $\mathrm{cm}^{-2}$ and $4.74 \times 10^{4}$ tracks $\mathrm{cm}^{-2}$, respectively. These values could be explained by the proximity of the sampling points and their location in a region without any geological faults, with emissions of $\mathrm{Rn}$ that were low and spatially similar, largely due to the sedimentary nature of the soil. In contrast, high track densities were found for the points located in the geological fault region, due to the greater intensity of radon emanation. For the sites P1 to P6, the nuclear track densities were, respectively, $10.09 \times 10^{4}$; $11.23 \times 10^{4} ; 8.57 \times 10^{4} ; 10.29 \times 10^{4} ; 9.69 \times 10^{4} ;$ and $12.24 \times 10^{4}$ tracks cm ${ }^{-2}$.

The relationship between the nuclear track density and mean concentration of the $\mathrm{Pb}$ within each soil profile (Fig. 3) was analyzed using Pearson correlation analysis. According to the result, the $\mathrm{Pb}$ concentration in the whole soil profile was shown to correlate with nuclear track density. The Pearson correlations $(r)$ were $0.992,0.991,0.864$ for 15, 30, and 60 depth, respectively. From the statistical analysis, it was found too that the $\mathrm{Pb}$ concentrations in the soil profile are correlated. The $p$ values (2-tailed) were lower than 0.01 , indicating that the relationship is statistically significant and then there is a $99 \%$ chance that the relationship is true. In this type of analysis, the results strongly suggest that geological faults are related the source of enhanced emissions of lead at this location.

\section{Conclusion}

Quantitative analysis of total $\mathrm{Pb}$ in soil samples from $\mathrm{P} 1-$ P6 points (in a geological fault region) revealed concentrations in the range from 271.22 to $843.30 \mathrm{mg} \mathrm{kg}^{-1}$, while

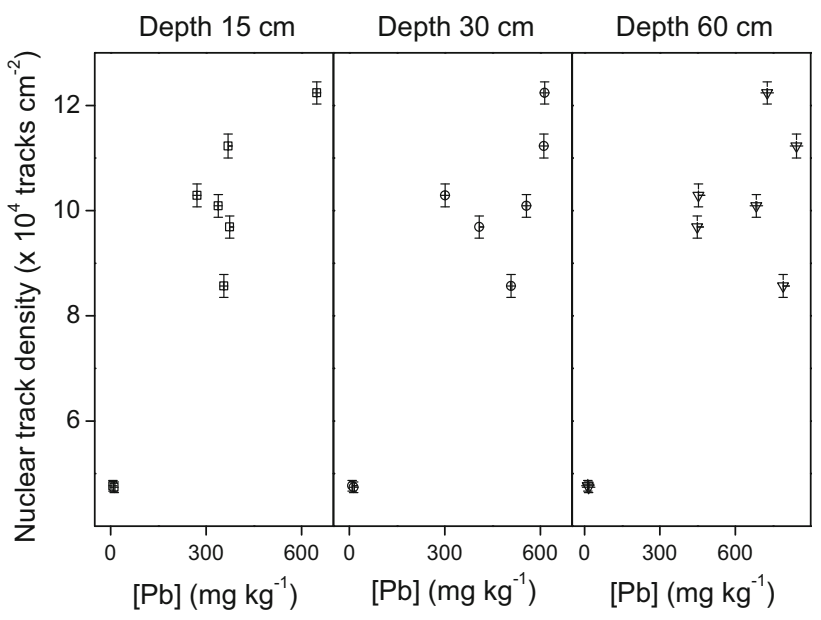

Fig. 3 Relationship between the nuclear track density and mean concentration of the $\mathrm{Pb}$ within each soil profile. The $\mathrm{p}$ values (2tailed) were $0.001,0.002,0.006$ for 15,30 , and 60 depth, respectively. From the statistical analysis, the results strongly suggest that geological faults are related the source of enhanced emissions of lead at this location

concentrations in samples from P7 and P8 points (in a region without faults) were much lower, ranging from 6.83 to $15.95 \mathrm{mg} \mathrm{kg}^{-1}$. The $\mathrm{Pb}$ concentrations increased systematically with horizon depth, which could be explained by the fact that the lead originated from radon emissions, which in turn were due to the presence of geological faults. It is important to note that the study area belong to Paraná Basin with stratigraphic age around 90 million years, enough time to accumulate big lead concentration.

Incubation of the soil cores in the bores resulted in large increases in $\mathrm{Pb}$ concentrations after 95 days, reflecting the effect of geological faults in increasing $\mathrm{Pb}$ levels. The greatest increases occurred in the deepest horizons, indicating that the origin of the lead was directly related to the emissions of radon gas from anomalies in the underlying rock layers. That is, during this time the incubations samples were contaminated with radon-lead through lixiviation effects.

Textural analysis revealed that the clay fraction percentage varied from 1.8 to $38.6 \%$ at the sample collection sites, and it could be concluded that the total $\mathrm{Pb}$ concentration increased with increasing clay content, reflecting the cation exchange capacity of clay. After incubation in the bores, the soil cores from P7 and P8 sites showed increases in $\mathrm{Pb}$ concentrations that were determined by the availability of clay, with the highest metal concentrations in the deepest horizons $(60 \mathrm{~cm})$ where the percentages of clay were also highest.

Comparison of the density values obtained for the CR39 detectors confirmed that $\mathrm{Rn}$ emissions were highest in the regions affected with geological faults. The data demonstrated that the presence of geological faults led to 
high concentrations of $\mathrm{Pb}$ in soil that are related to the emissions of radon and would therefore require appropriate intervention actions.

Acknowledgements Authors acknowledge National Council of Scientific and Technology Development-CNPq (234256/2014-1 and $302728 / 2012-0$ ) for the financial support. SJT :

\section{References}

Alleoni LRF, Peixoto RTD, de Azevedo AC, Melo LCA (2009) Components of surface charge in tropical soils with contrasting mineralogies. Soil Sci 174:629-638. doi:10.1097/SS. 0b013e3181c17a93

Alloway BJ, Jackson AP, Morgan H (1990) The accumulation of cadmium by vegetables grown on soils contaminated from a variety of sources. Sci Total Environ 91:223-236. doi:10.1016/ 0048-9697(90)90300-J

Amaral PGQ, Galembeck TMB, Bonotto DM, Artur AC (2012) Uranium distribution and radon exhalation from Brazilian dimension stones. Appl Radiat Isot 70:808-817. doi:10.1016/j. apradiso.2011.10.010

Assumpcao M, Marza V, Barros L, Chimpliganond C, Soares JE, Carvalho J, Caixeta D, Amorim A, Cabral E (2002) Reservoirinduced seismicity in Brazil. Pure appl Geophys 159:597-617. doi:10.1007/P100001266

Batiot-Guilhe C, Seidel JL, Jourde H, Hebrard O, Bailly-Comte V (2007) Seasonal variations of $\mathrm{CO} 2$ and $\mathrm{Rn}-222$ in a mediterranean sinkhole-spring (Causse d'Aumelas, SE France). Int J Speleol 36:51-56

Bielicki KH, Tischendorf G (1991) Lead isotope and $\mathrm{Pb}-\mathrm{Pb}$ model age-determinations of ores from central-Europe and their metallogenetic interpretation. Contrib Miner Petrol 106:440-461. doi:10.1007/Bf00321987

Bochicchio F, Forastiere F, Abeni D, Rapiti E (1998) Epidemiologic studies on lung cancer and residential exposure to radon in Italy and other countries. Radiat Prot Dosimetry 78:33-38

Carter MR, Gregorich EG (2008) Soil sampling and methods of analysis, 2nd edn. Canadian Society of Soil Science; CRC Press, Pinawa, Manitoba, Boca Raton, FL

Chen M, Ma LQ (1998) Comparison of four USEPA digestion methods for trace metal analysis using certified and Florida soils. J Environ Qual 27:1294-1300

Chmielewska I, Chalupnik S, Bonczyk M (2014) Natural radioactivity in drinking underground waters in Upper Silesia and solid wastes produced during treatment. Appl Radiat Isotopes 93:96-100. doi:10.1016/j.apradiso.2014.01.017

Chyi LL, Quick TJ, Yang TF, Chen CH (2005) Soil gas radon spectra and earthquakes. Terr Atmos Ocean Sci 16:763-774

Elom NI, Entwistle J, Dean JR (2014) Human health risk from Pb in urban street dust in northern UK cities. Environ Chem Lett 12:209-218. doi:10.1007/s10311-013-0436-0

Espinosa G, Golzarri JI, Bogard J, Gaso I, Ponciano G, Mena M, Segovia N (2008a) Indoor radon measurements in Mexico City. Radiat Meas 43:S431-S434. doi:10.1016/j.radmeas.2008.03.039

Espinosa G, Golzarri JI, Gammage RB, Sajo-Bohus L, Viccon-Pale J, Signoret-Poillon A (2008b) Seasonal variation measurements of radon levels in caves using SSNTD method. Radiat Meas 43:S364-S368. doi:10.1016/j.radmeas.2008.04.033

Godoy M (2006) Fratura ao norte de Presidente Prudente deve ter causado tremor: Geólogo atribuiu abalo que atingiu 4 cidades na região ao alinhamento Guapiara (Fracture at north of Presidente Prudente must have caused tremor: Geologist attributed quake which hit four cities in the region the Guapiara alignment), Jornal Oeste Notícias, Presidente Prudente (Brazil)

Hettiarachchi GM, Pierzynski GM (2004) Soil lead bioavailability and in situ remediation of lead-contaminated soils: a review. Environ Prog 23:78-93. doi:10.1002/ep.10004

Inan S, Kop A, Cetin H, Kulak F, Pabuccu Z, Seyis C, Ergintav S, Tan O, Saatcilar R, Bodur MN (2012) Seasonal variations in soil radon emanation: long-term continuous monitoring in light of seismicity. Nat Hazards 62:575-591. doi:10.1007/s11069-0120096-6

Kabata-Pendias A, Mukherjee AB (2007) Trace Elements from soil to human. Springer, Berlin

Katsanos AA, Tassios DP, Zeliotis ND (1966) A new method for analysis in low concentrations using radioisotopes in polarography. J Electroanal Chem 11:36-43. doi:10.1016/00220728(66)80056-6

Kharatian K, Travi Y, Igoumnov V (2002) Radon soil-gas concentrations and local seismicity: case of the Arax basin (Armenia). CR Geosci 334:179-185. doi:10.1016/S1631-0713(02)01724-8

Knizhnik EI, Prokopenko VS, Stolyarov SV, Tokarevskii VV (1994) Cr-39 plastic track detector for field investigations of alphaactive soils. At Energ 76:105-111. doi:10.1007/Bf02414351

Kuptsov VM (1990) Hydrothermal radon in natural-water of Juan-DeFuca Rift-Zone (the Pacific-Ocean, 45-degrees-N). Geokhimiya 2:285-289

Kurczewska J, Grzesiak P, Lukaszyk J, Gabala E, Schroeder G (2015) High decrease in soil metal bioavailability by metal immobilization with halloysite clay. Environ Chem Lett 13:319-325. doi:10.1007/s10311-015-0504-8

Lagerwer JV, Specht AW (1970) Contamination of roadside soil and vegetation with cadmium, nickel, lead, and zinc. Environ Sci Technol 4:583-586. doi:10.1021/Es60042a001

Lerman A, Lal D, Dacey MF (1974) Stokes' settling and chemical reactivity of suspended particles in natural waters. Plenium Press, New York

Matiullah Ahmad N, Durrani SA, Kudo K (1990) A review of the use of Cr-39 track detector in personnel neutron dosimetry and spectrometry. Nucl Instrum Methods Phys Res Sect B Beam Interact Mater Atoms 51:76-84. doi:10.1016/0168$583 \times(90) 90542-3$

Ming H, He WX, Lamb DT, Megharaj M, Naidu R (2012) Bioavailability of lead in contaminated soil depends on the nature of bioreceptor. Ecotox Environ Safe 78:344-350. doi:10. 1016/j.ecoenv.2011.11.045

Miretzky P, Munoz C, Carrillo-Chavez A (2007) A sandy loam soil as a natural control for $\mathrm{Pb}$ contamination. Environ Chem Lett 5:131-136. doi:10.1007/s10311-007-0093-2

Nevinsky V, Nevinsky I, Tsvetkova T (2012) Measurements of soil radon in south Russia for seismological application: methodological aspects. Radiat Meas 47:281-291. doi:10.1016/j. radmeas.2012.02.008

Olszowy H, Imray P, Torr P, Services ADoH, Health, Agency ACEP, Commission SAH, Agency EP, (1995) Trace element concentrations in soils from rural and urban areas of Australia. South Australian Health Commission

Pereira LAS, Saenz CAT, Constantino CJL, Curvo EAC, Dias ANC, Soares CJ, Guedes S (2013) Micro-Raman spectroscopic characterization of a CR-39 detector. Appl Spectrosc 67:404-408. doi:10.1366/12-06741

Poortinga W, Bronstering K, Lannon S (2011) Awareness and perceptions of the risks of exposure to indoor radon: a population-based approach to evaluate a radon awareness and testing campaign in England and Wales. Risk Anal 31:1800-1812. doi:10.1111/j.1539-6924.2011.01613.x

Proença CA, Borsato N, Maroubo L, Moreira-Silva MR, Teixeira MFS (2016) Simultaneous determination of $\mathrm{Cd}, \mathrm{Pb}$, and $\mathrm{Cu}$ in 
atmospheric particulate matter from different regions of the city of Presidente Prudente, Sao Paulo, Brazil. Chem Ecol 36:598-607. doi:10.1080/02757540.2016.1171321

Raaen HP (1974) Radioelectrochemistry-review. Anal Chem 46:1265-1292. doi:10.1021/Ac60345a003

Shaheen SM, Tsadilas CD, Rinklebe J (2013) A review of the distribution coefficients of trace elements in soils: influence of sorption system, element characteristics, and soil colloidal properties. Adv Colloid Interface Sci 201:43-56. doi:10.1016/j. cis.2013.10.005

Tack FMG, Verloo MG (1995) Chemical speciation and fractionation in soil and sediment heavy-metal analysis-a review. Int J Environ Anal Chem 59:225-238. doi:10.1080/03067319508041330

Turpeinen R, Salminen J, Kairesalo T (2000) Mobility and bioavailability of lead in contaminated boreal forest soil. Environ Sci Technol 34:5152-5156. doi:10.1021/es001200d
Xian X (1989) Effect of chemical forms of cadmium, zinc, and lead in polluted soils on their uptake by cabbage plants. Plant Soil 113:257-264. doi:10.1007/Bf02280189

Yang HD, Appleby PG (2016) Use of lead-210 as a novel tracer for lead $(\mathrm{Pb})$ sources in plants. Sci Rep Uk. doi:10.1038/Srep21707

Yang TF, Walia V, Chyi LL, Fu CC, Chen CH, Liu TK, Song SR, Lee CY, Lee M (2005) Variations of soil radon and thoron concentrations in a fault zone and prospective earthquakes in SW Taiwan. Radiat Meas 40:496-502. doi:10.1016/j.radmeas. 2005.05.017

Zia MH, Codling EE, Scheckel KG, Chaney RL (2011) In vitro and in vivo approaches for the measurement of oral bioavailability of lead $(\mathrm{Pb})$ in contaminated soils: a review. Environ Pollut 159:2320-2327. doi:10.1016/j.envpol.2011.04.043 